\title{
Cryopreservation and In Vitro banking: a cool subject - Preface from the editors
}

\author{
Sergio Ochatt ${ }^{1} \cdot$ Maurizio Lambardi $^{2} \cdot$ Bart Panis $^{3} \cdot$ Ranjith Pathirana $^{4} \cdot$ Maria Angeles Revilla $^{5} \cdot$ Qiao-Chun Wang $^{6}$
}

Published online: 6 January 2021

○ The Author(s), under exclusive licence to Springer Nature B.V. part of Springer Nature 2021

Plant breeding depends largely on having access to a wide variety of plant genetic resources, which are vulnerable to losses caused by biotic and abiotic threats when grown in the field or in a greenhouse. Thus, cryopreservation or in vitro banking is a safe strategy for long-term conservation of such genetic resources, which serves as back-up collections for field genebanks and reduces risks of genetic drift or losses of precious genotypes.

There are many reports describing efficient cryopreservation protocols but few of them are already routinely used for long-term conservation. A common problem is the difficulty of transferring technology and validating protocols from one laboratory to another. Indeed, there are many critical factors involved including: the quality and type of plant materials, pretreatment and preculture conditions, cryopreservation methods, cooling, storage and warming conditions, and regrowth assessment methods. In addition, adequate facilities and skilled technical staff are required.

Shoot tips and embryogenic cultures are the tissues most frequently used in plant cryopreservation, but small

Sergio Ochatt

sergio.ochatt@inrae.fr

1 UMR 1347 Agroécologie, AgroSup/INRAE/uBFC, 17 rue Sully, F-21000 Dijon, France

2 CNR-IBE, Institute of BioEconomy, National Research Council (CNR), Via Madonna de Piano 10, 50019 Sesto Fiorentino, Florence, Italy

3 Bioversity International @ KU Leuven, Willem de Croylaan 42, 3001 Leuven, Belgium

4 Plant \& Food Research Australia Pty Ltd, Waite Campus Research Precinct - WT46, Waite Rd, Urrbrae, SA 5064, Australia

5 Departamento de Biología de Organismos y Sistemas, Universidad de Oviedo, Area de Fisiología Vegetal, C/ C. Rodrigo Uría s/n, 33007 Oviedo, Spain

$6 \quad$ State Key Laboratory of Crop Stress Biology for Arid Areas, College of Horticulture, Northwest A\&F University, Yangling 712100, Shaanxi, People's Republic of China leaf square-bearing adventitious buds, stem disc-bearing adventitious buds, microtubers and rhizome buds are alternative explants together with root explants, seeds, pollen or winter dormant buds directly collected from field plants. Maintenance of the genetic stability, as well as biochemical, physiological, and metabolic characteristics in regenerants after cryo-storage are the major concerns. All these aspects have been addressed in the 26 articles included in this Special Issue of Plant Cell Tissue and Organ Culture. While still online only, they have already attracted great interest as about 5000 reads and more than 10 citations have been recorded. This Special Issue starts with four review articles, which are followed by 10 studies where meristems, shoot tips or budwood belonging to different species were the cryopreserved explants, five using embryogenic tissues or somatic embryos and seeds, and two reports on the cryopreservation of pollen, while five manuscripts addressed more fundamental aspects of these issues.

In a comprehensive review, Wang et al. (2021a) discussed advances in cryopreservation techniques that have facilitated the conservation of a range of explants and germplasms presently preserved in cryobanks. The droplet freezing method, developed for cryopreservation of sweet potato meristems, is based on inclusion of explants in microdroplets of the cryoprotectant DMSO, placed in groups of 4-5 drops over aluminum strips. When PVS2 or PVS3 (Plant Vitrification Solution 2 or 3 ) are used to form the microdroplets, the method is named droplet vitrification. After a historic overview of the general background in cryopreservation, the authors examined droplet vitrification-based techniques and cryo-plate-based methods, then compared results among them. Readers will value the various schemes and comprehensive tables included in this review paper.

In a similarly compelling review, Bettoni et al. (2021) examined the challenges that still require optimization for successful implementation of the cryopreservation procedures to shoot tips. The difficulties for technology transfer between laboratories, which has often slowed down and 
sometimes even impeded protocol validation, were discussed and most critical factors involved were clearly identified. These practical aspects should attract the attention of readers and assist the implementation of cryopreservation of shoot tips in cryo-banks.

This was followed by the review of Tanner et al. (2021) addressing cryopreservation of dormant buds, a cryotechnique that is presently suitable for deciduous trees and shrubs but is a season-dependent work. Solutions to specific key parameters must be defined according to institutional resources when attempting to perform large scale implementation of dormant bud cryopreservation.

Adventitious and hairy roots have scientific and commercial interests as an alternative source of plant-derived bioactive compounds with potential application in pharmaceutical, cosmetic, and natural health product industries. The review of Popova et al. (2021) summarizes the results of recent studies on cryopreservation of plant roots and highlights the importance of continued research in this area. Although cryopreservation procedure did not significantly affect growth, biosynthetic and genetic stability of roots following recovery in an ambient growth environment, root tips are very sensitive to any stress caused by various steps of a cryopreservation protocol, and careful optimization of each step, particularly exposure to vitrification solution, is necessary.

In this special issue, Sharma et al. (2021) compared conventional vitrification with droplet vitrification in Gentiana kurroo Royle, a critically endangered medicinal plant endemic to the North-Western Himalayas, where poor seed germination and harvesting of rhizomes has rendered this species severely threatened in the wild. The droplet vitrification method permitted an almost two-fold higher survival rate in the three accessions studied, provided it included 4 weeks of cold acclimation of shoot tips from 8-week-old stock plants at $8{ }^{\circ} \mathrm{C}$ in the dark and 30 min treatment in plant vitrification solution at $0{ }^{\circ} \mathrm{C}$. Genetic fidelity of the regenerated plants was confirmed and the protocol developed is being applied for long-term conservation of this species in cryo-banking.

Aimed at an efficient micropropagation procedure for maintaining the biodiversity and elite genotypes of Physalis angulata L., Romo-Paz et al. (2021) developed methods for cryopreservation via droplet vitrification of this species of food and medicinal interest and found that exposure of shoot tips from one-month-old in vitro plants to PVS2 for 30 min was superior.

Rantala et al. (2021) applied a modified PVS2 droplet vitrification method for cryopreservation of 22 blackcurrant (Rubus nigrum L.) accessions propagated in vitro and selected from the Finnish national gene bank core collection. Differently from the classic procedure, each foil contained three droplets each with 3-4 shoot tips. Recovery of shoot tips after 9 weeks was at least $75 \%$ in 7 accessions and $40 \%$ in 19 out of 22 accessions. Thus, cryopreservation by this technique is useful for blackcurrant long-term ex situ conservation but differences in shoot-tip recovery among cultivars must not be underestimated.

Maślanka and Szewczyk (2021) described a vitrification protocol for cryopreservation of Tulipa tarda Stapf. apical meristems derived from bulblets. Cold-hardening bulblets at $5{ }^{\circ} \mathrm{C}$ for 10 weeks secured $100 \%$ regrowth of cryopreserved meristems, avoiding risks of somaclonal variation in adventive de novo shoots formed from callus due to cryoinjury.

The explant size and age of the mother plant affect the survival after cryopreservation as shown by Pathirana et al. (2021) in five Actinidia species, where the use of both smaller shoot tips and younger mother shoots, pretreated in liquid sucrose media in the dark significantly improved plant regeneration after droplet vitrification cryopreservation of kiwifruit. The method described is currently being used for long-term conservation of kiwifruit germplasm in New Zealand.

In a groundbreaking study, O'Brien et al. (2021) reported the successful cryopreservation of avocado shoot tips from mature material, with more vigorous plants obtained using a newly developed vitrification solution instead of PVS2. This work may pave the way for the setup of a world's first germplasm repository to store a core collection of Persea spp.

Tanaka et al. (2021) adapted the D-cryo-plate protocol to garlic (Allium sativum L. cultivar White) enabling the storage of shoot tips either at $-80^{\circ} \mathrm{C}$ or in liquid nitrogen, subsequently extended to four genotypes of A. fistulosum $\mathrm{L}$. (Japanese shallot) and A. chinense (rakkyo). Interestingly, the glass transition temperature of garlic samples conserved by $\mathrm{D}$ cryo-plate method is -39.4 to $-44.7{ }^{\circ} \mathrm{C}$, and thus much higher than that by vitrification (around $-115^{\circ} \mathrm{C}$ ) allowing long-term conservation of germplasm in a deep freezer at $-80{ }^{\circ} \mathrm{C}$.

Evaluating the growth and development of plants obtained following cryopreservation is crucial. In this issue, Wang et al. (2021b) showed that cryopreserved shallot plants maintained their rooting capacity, vegetative growth, bulb production, genetic stability, and biochemical compounds, being true-to-type.

Mathew et al. (2021) reported that combining cryotherapy with chemotherapy or thermotherapy significantly improved the efficiency of eradication of raspberry bushy dwarf virus (RBDV) from the infected in vitro-cultured red raspberry (Rubus ideaus), as determined by TaqMan-based real-time One-Step RT-PCR assay.

Maintenance of germplasm of fast-growing in vitro tissues in genebanks is generally problematic and requires frequent subculturing. To sidestep this, de Lacerda et al. (2021) developed an in vitro conservation method using mineral oil and low temperature for nodal segments of two species, 
Pfaffia glomerata and Lippia filifolia. They found that the tissues can be maintained for up to 360 days in $5 \mathrm{ml}$ mineral oil at $15{ }^{\circ} \mathrm{C}$, with $100 \%$ survival for the former and $>50 \%$ for the latter, and this without the formation of any morphoanatomical abnormalities despite the low oxygen availability imposed by submersion in oil.

Ree and Guerra (2021) reported that regrowth of embryogenic clusters of peach palm (Bactris gasipaes Kunth) was improved by adding inorganic ions in diluted PVS3, with larger embryogenic clusters responding better than smaller ones. Increasing the length of rewarming time had no significant effect on survival, suggesting that the most critical events occur within the first minute of rewarming.

Manokari et al. (2021) established an efficient protocol for asymbiotic seed germination of the grey orchid (Vanda tessellata (Roxb.) Hook. ex G.Don). Subsequently, they induced somatic embryogenesis resulting in $91 \%$ of encapsulated somatic embryos regenerating after 1 year of cold storage at $4{ }^{\circ} \mathrm{C}$.

Peng et al. (2021) improved regeneration rates of somatic embryos and cryopreserved embryogenic tissues of Korean pine, Pinus koraiensis, with $90 \%$ survival after cryopreservation. This could resolve the problem of gradual loss of somatic embryogenesis potential of Korean pine after 6 months of subculture.

In a study with Ensete glaucum, a crop wild relative of banana, Singh et al. (2021) proved the utility of air-dehydration as a critical step in the cryopreservation of seeds and excised zygotic embryos in two accessions of this species, which are now conserved in vitro in the Genebank of ICARNBPGR, in India.

Gladfelter et al. (2021) achieved somatic embryogenesis from immature zygotic embryos of Stewartia, a genus of flowering shrubs and trees in the family Theaceae which includes species that are difficult to propagate and others which are rare or endangered. They tested 17 genotypes from six different Stewartia species for their cryopreservation ability and recovered $100 \%$ of embryogenic tissues of five genotypes from four species after cryo-storage for at least 1 year.

Araújo de Oliveira et al. (2021) optimized in vitro pollen germination conditions for five date palm cultivars (Phoenix dactylifera $\mathrm{L}$.). After storage in liquid nitrogen vapor (LNV) their viability remained stable for 9 months. Pollen also remained viable when cooled to and warmed from LNV for up to 60 cycles, suggesting that this protocol could be implemented to prolong the duration of storage across multiple seasons and secure pollen long-term preservation of the 49 male trees in genebank cryostorage at the National Laboratory for Genetic Resources Preservation in Fort Collins, CO (USA).

Plants are complex biological systems comprising thousands of different genes, proteins, regulatory molecules, and chemical compounds that form hundreds of interlinked pathways and networks. Cryopreservation-induced oxidative stress disrupts intracellular homeostasis and the balance between reactive oxygen species (ROS) production and clearance. As antioxidant systems affect cryopreservation success, monitoring the activity of key enzymes can help to understand plant metabolism during cryopreservation thus improving recovery of cryopreserved plant material. The final five articles in this issue address these aspects from different viewpoints using different species.

Ren et al. (2021) reported the cryopreservation-induced production of malondialdehyde and protein carbonyls, oxidation products of cell wall lipids and cellular proteins, respectively, in pollen of three Paeonia suffruticosa cultivars differing in amenability to cryopreservation. It is suggested that the oxidative damage of membrane lipids and proteins caused by ROS is the main reason for loss of viability after cryopreservation. Thus, efficient clearing of cytotoxic ROS components via the enzymatic antioxidant superoxide dismutase and the non-enzymatic antioxidants glutathione and ascorbic acid, helped to maintain the balance of intracellular oxidative metabolism, and membrane lipid and cellular protein integrity.

In lettuce seeds, Han et al. (2021) showed that parthenolide, a repressor of ring-finger-type ubiquitin E3 ligase, can disrupt the expression pattern of $C O P 1$ and cold responsive genes and reduce the level of small molecular chaperons and the proteolysis of seed globulins. RNA-seq and RT-PCR data showed that parthenolide affected the function of endoplasmic reticulum associated degradation, while proteomic studies indicated that it inhibited the proteolysis of seed storage globulins responsible for the reduced freezing tolerance of the hydrated lettuce seeds.

Padilla et al. (2021) encapsulated nodal segments of neem (Azadirachta indica A. Juss.) in vitro plantlets in alginate beads, and stored them for 4 weeks at $12{ }^{\circ} \mathrm{C}$. The viability increased to $75 \%$ when the nodal segments were pre-treated with $25 \mu \mathrm{M}$ acetylsalicylic acid for 4 weeks prior to encapsulation compared to just $20 \%$ in the control. This improved antioxidant defense of buds and seemed to protect the cell membranes, as observed by the lipid peroxidation results. This study provided an easy, cheap and practical method to preserve in vitro culture material and collections of this species for laboratory exchange but also for short-term storage.

In their work with Arabidopsis, Zhang et al. (2021) reported that application of two recombinant dehydrins (members of the late embryogenesis abundant [LEA] proteins) from Agapanthus praecox doubled the survival rate of seedlings by decreasing damage to the cell membrane during cryopreservation. Dehydrins reduced excessive ROS production and peroxidation damage of membrane lipids under the complex stress damage resulting from cryopreservation. Hence, when added during the dehydration step, dehydrins 
can relieve cryo-injury through the induction of high antioxidant levels and positive oxidative stress responses whereby they act as protectants.

Also working with Arabidopsis, Ekinci et al. (2021) revealed microRNA-based post-transcriptional regulation during different stages of cryopreservation of seedlings that germinated in vitro. They screened 10 miRNAs and their selected target genes and proved that the alteration of the expression levels of cold-induced and oxidative stressinduced genes related-miRNAs (especially miR393) play a key role in the success of cryopreservation. Noteworthy, results observed with miRNAs associated with drought and developmental stages also pointed to a decreased stress tolerance due to the prolonged germination time during shortterm cryostorage.

The study of Kamińska et al. (2021) addressed the storage of Taraxacum pieninicum synthetic seeds under slowgrowth conditions, in combination with abscisic acid (ABA) treatment. Darkness favoured synseed storage and did not generate additional stress during cold exposure compared to light conditions. ABA inhibited the growth of encapsulated shoot tips during cold storage and biochemical parameters showed that such treatment effectively reduced the negative effect of cold stress. Moreover, synseeds stored under light conditions and treated with $\mathrm{ABA}$ exhibited decreased level of endogenous jasmonic acid, indicative of an interaction between those two phytohormones at low temperature. Such limited growth contributed to an extended storage of the $T$. pieninicum explants up to 9 months, without affecting postconservation regrowth and flowering after acclimatization ex vitro.

For many species, encapsulation technologies can be a promising tool for the management of plant material of high quality, the production in nurseries of plants from in vitro culture, or the conservation of plant genetic resources. Such "synthetic seeds" proved to be of great value in the medium(slow-growth storage) and long-term (cryopreservation) conservation of germplasm of fruit, ornamental, horticultural and forestry species in small spaces. However, more research is still needed. Cryopreservation projects must have clear goals, long-term funding, skilled technical support staff, necessary infrastructure, and well-defined procedures and protocols, so that they can be routinely implemented in plant cryobanks and help to establish backup collections of valuable plant genetic resources.

\section{References}

Araújo de Oliveira AC, da Silva Lédo A, Polek M, Krueger R, Shepherd A, Volk GM (2021) Optimization of in vitro germination and cryopreservation conditions for preserving date palm pollen in the USDA National Plant Germplasm System. Plant Cell Tissue Organ Cult. https://doi.org/10.1007/s11240-020-01907-1

Bettoni JC, Bonnart R, Volk GM (2021) Challenges in implementing plant shoot tip cryopreservation technologies. Plant Cell Tissue Organ Cult. https://doi.org/10.1007/s11240-020-01846-x

de Lacerda LF, Gomes HT, Bartos PMC, Vasconcelos JM, Vasconcelos Filho SC, Silva-Cardoso IMA, Scherwinski-Pereira JE (2021) Growth, anatomy and histochemistry of fast growing species under in vitro conservation through mineral oil and lowtemperature combination. Plant Cell Tissue Organ Cult. https:// doi.org/10.1007/s11240-020-01821-6

Ekinci MH, Kayıhan DS, Kayıhan C, Çiftçi YÖ (2021) The role of microRNAs in recovery rates of Arabidopsis thaliana after short term cryo-storage. Plant Cell Tissue Organ Cult. https://doi. org/10.1007/s11240-020-01811-8

Gladfelter HJ, Johnston J, Wilde HD, Merkle SA (2021) Somatic embryogenesis and cryopreservation of Stewartia species. Plant Cell Tissue Organ Cult. https://doi.org/10.1007/s11240-02001834-1

Han Y, Yu Y, Zhou J, Jaganathan GK, Shen M, Zhou Q, Song D, Liu B (2021) Parthenolide reduces the freezing tolerance of hydrated lettuce seeds by inhibiting the proteolysis of seed storage globulins. Plant Cell Tissue Organ Cult. https://doi.org/10.1007/s1124 0-020-01836-Z

Kamińska M, Kęsy J, Trejgell A (2021) Abscisic acid in preservation of Taraxacum pieninicum in the form of synthetic seeds in slow growth conditions. Plant Cell Tissue Organ Cult. https://doi. org/10.1007/s11240-020-01924-0

Manokari M, Latha R, Priyadharshini S, Jogam P, Shekhawat MS (2021) Short-term cold storage of encapsulated somatic embryos and retrieval of plantlets in grey orchid (Vanda tessellata (Roxb.) Hook. ex G.Don). Plant Cell Tissue Organ Cult. https://doi. org/10.1007/s11240-020-01899-y

Maślanka M, Szewczyk A (2021) Droplet-vitrification cryopreservation of Tulipa tarda Stapf. apical meristems. Plant Cell Tissue Organ Cult. https://doi.org/10.1007/s11240-020-01910-6

Mathew L, Tiffin H, Erridge Z, McLachlan A, Hunter D, Pathirana R (2021) Efficiency of eradication of Raspberry bushy dwarf virus from infected raspberry (Rubus idaeus) by in vitro chemotherapy, thermotherapy and cryotherapy and their combinations. Plant Cell Tissue Organ Cult. https://doi.org/10.1007/s11240-020-01829-y

O'Brien C, Hiti-Bandaralage JCA, Folgado R, Lahmeyer S, Hayward A, Folsom J, Mitter N (2021) First report on cryopreservation of mature shoot tips of two avocado (Persea americana Mill.) rootstocks. Plant Cell Tissue Organ Cult. https://doi.org/10.1007/ s11240-020-01861-y

Padilla IMG, Barba-Espín G, Hernández JA, Piqueras A, Burgos L (2021) Acetylsalicylic acid improved antioxidative status and cold storage of encapsulated nodal segments of neem (Azadirachta indica A. Juss.). Plant Cell Tissue Organ Cult. https://doi. org/10.1007/s11240-020-01828-Z

Pathirana R, Mathew L, McLachlan A (2021) A simplified method for high recovery of kiwifruit (Actinidia spp.) shoot tips after droplet vitrification cryopreservation suitable for long-term conservation. Plant Cell Tissue Organ Cult. https://doi.org/10.1007/s1124 0-020-01860-z

Peng C, Gao F, Wang H, Shen H, Yang L (2021) Optimization of maturation process for somatic embryo production and cryopreservation of embryogenic tissue in Pinus koraiensis. Plant Cell Tissue Organ Cult. https://doi.org/10.1007/s11240-020-01918-y

Popova E, Shukla M, Kim H-H, Saxena PK (2021) Root cryobanking: an important tool in plant cryopreservation. Plant Cell Tissue Organ Cult. https://doi.org/10.1007/s11240-020-01859-6

Rantala S, Kaseva J, Nukari A, Laamanen J, Tuohimetsä S, Karhu S, Veteläinen M, Häggman H (2021) Droplet vitrification technique for cryopreservation of a large diversity of blackcurrant (Ribes 
nigrum L.) cultivars. Plant Cell Tissue Organ Cult. https://doi. org/10.1007/s11240-020-01841-2

Ree JF, Guerra MP (2021) Exogenous inorganic ions, partial dehydration, and high rewarming temperatures improve peach palm (Bactris gasipaes Kunth) embryogenic cluster post-vitrification regrowth. Plant Cell Tissue Organ Cult. https://doi.org/10.1007/ s11240-020-01852-Z

Ren R, Li Z, Zhang L, Zhou H, Jiang X, Liu Y (2021) Enzymatic and nonenzymatic antioxidant systems impact the viability of cryopreserved Paeonia suffruticosa pollen. Plant Cell Tissue Organ Cult. https://doi.org/10.1007/s11240-020-01794-6

Romo-Paz FJ, Folgado R, Delgado-Aceves L, Zamora-Natera JF, Portillo L (2021) Tissue culture of Physalis angulata L. (Solanaceae): techniques for micropropagation and germplasm long-term preservation. Plant Cell Tissue Organ Cult. https://doi.org/10.1007/ s11240-020-01970-8

Sharma N, Gowthami R, Devi SV, Malhotra EV, Pandey R, Agrawal A (2021) Cryopreservation of shoot tips of Gentiana kurroo Royle - a critically endangered medicinal plant of India. Plant Cell Tissue Organ Cult

Singh S, Thangjam R, Harish GD, Singh H, Kumar R, Meena DPS, Agrawal A (2021) Conservation protocols for Ensete glaucum, a crop wild relative of banana, using plant tissue culture and cryopreservation techniques on seeds and zygotic embryos. Plant Cell Tissue Organ Cult. https://doi.org/10.1007/s11240-020-01881-8

Tanaka D, Sakuma Y, Yamamoto S, Valle Arizaga A, Niino T, Matsumoto T (2021) Development of $-80{ }^{\circ} \mathrm{C}$ storage for Allium shoot tips using D cryo-plate method. Plant Cell Tissue Organ Cult. https://doi.org/10.1007/s11240-020-01956-6

Tanner JD, Chen KY, Bonnart RM, Minas IS, Volk GM (2021) Considerations for large-scale implementation of dormant budwood cryopreservation. Plant Cell Tissue Organ Cult. https://doi. org/10.1007/s11240-020-01884-5

Wang MR, Lambardi M, Engelmann F, Pathirana R, Panis B, Volk GM, Wang QC (2021a) Advances in cryopreservation of in vitroderived propagules: technologies and explant sources. Plant Cell Tissue Organ Cult. https://doi.org/10.1007/s11240-020-01770-0

Wang MR, Hamborg Z, Slimestad R, Elameen A, Blystad DR, Haugslien S, Skjeseth G, Wang QC (2021b) Assessments of rooting, vegetative growth, bulb production, genetic integrity and biochemical compounds in cryopreserved plants of shallot. Plant Cell Tissue Organ Cult. https://doi.org/10.1007/s11240-020-01820-7

Zhang D, Yang T, Ren L (2021) $\mathrm{Y}_{2} \mathrm{SK}_{2}$ - and $\mathrm{SK}_{3}$-type dehydrins from Agapanthus praecox act as protectants to improve plant cell viability during cryopreservation. Plant Cell Tissue Organ Cult. https:// doi.org/10.1007/s11240-020-01780-y

Publisher's Note Springer Nature remains neutral with regard to jurisdictional claims in published maps and institutional affiliations. 